\title{
Corrigendum: Radiology subspecialisation in Africa: A review of the current status
}

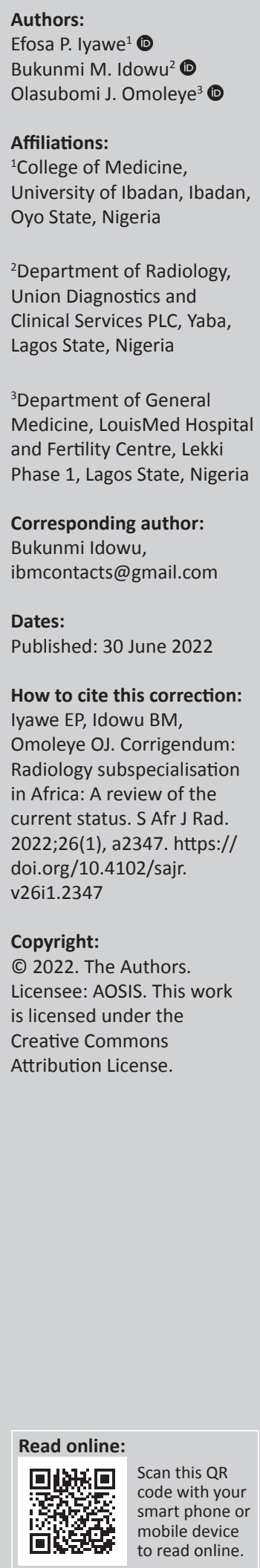

Published: 30 June 2022

How to cite this correction: lyawe EP, Idowu BM, Omoleye OJ. Corrigendum: Radiology subspecialisation in Africa: A review of the current status. S Afr J Rad. 2022;26(1), a2347. https:// doi.org/10.4102/sajr. v26i1.2347

\section{Copyright:}

(C) 2022. The Authors.

Licensee: AOSIS. This work

is licensed under the

Creative Commons

Attribution License.

In the published article, Iyawe EP, Idowu BM, Omoleye OJ. Radiology subspecialisation in Africa: A review of the current status. S Afr J Rad. 2021;25(1):a2168. https://doi.org/10.4102/sajr. v25i1.2168, on page 4 the following paragraph is updated as it was incorrectly formulated:

The original incorrect wording:

The Tanzanian IR project was midwifed by the RAD-AID International IR programme in collaboration with academic institutions in the United States and Europe.

The revised and updated wording:

The Tanzanian IR project was midwifed by the Radiological Society of North America (RSNA) and an organisation called Road2IR (www.road2ir.org).

The authors apologise for this error. The correction does not change the significance of study's findings or overall interpretation of its results or the scientific conclusions in any way. 


\section{Radiology subspecialisation in Africa: $A$ review of the current status}

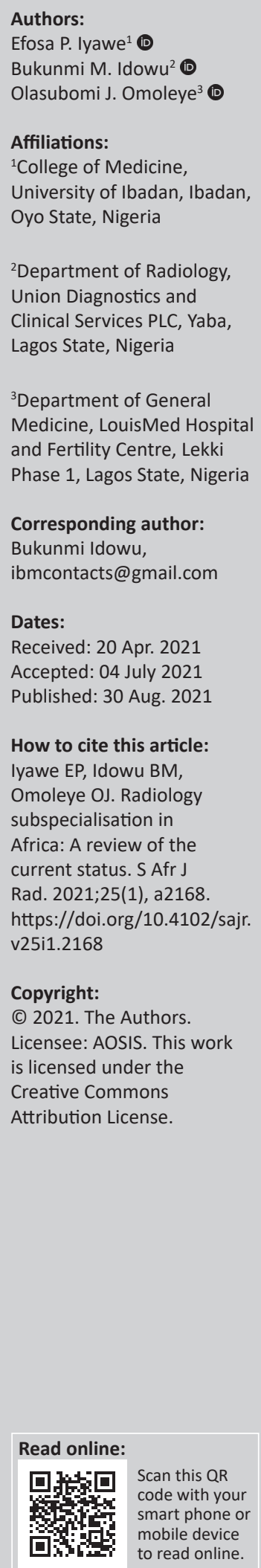

Background: Radiology subspecialisation is well-established in much of Europe, North America, and Australasia. It is a natural evolution of the radiology speciality catalysed by multiple factors.

Objectives: The aim of this article is to analyse and provide an overview of the current status of radiology subspecialisation in African countries.

Methods: We reviewed English-language articles, reports, and other documents on radiology specialisation and subspecialisation in Africa.

Results: There are 54 sovereign countries in Africa (discounting disputed territories). Eighteen African countries with well-established radiology residency training were assessed for the availability of formal subspecialisation training locally. Eight (Egypt, Ethiopia, Kenya, Morocco, Nigeria, South Africa, Tanzania, and Tunisia) out of the 18 countries have local subspecialist training programmes. Data and/or information on subspecialisation were unavailable for three (Algeria, Libya, and Senegal) of the 18 countries. Paediatric Radiology (Ethiopia, Nigeria, South Africa, Tunisia) and Interventional Radiology (Egypt, Kenya, South Africa, Tanzania) were the most frequently available subspecialist training programmes. Except Tanzania, all the countries with subspecialisation training programmes have $\geq 100$ radiologists in their workforce.

Conclusion: There is limited availability of subspecialist radiology training programmes in African countries. Alternative models of subspecialist radiology training are suggested to address this deficit.

Keywords: Africa; curriculum; education; radiology; specialist training; subspecialisation; web-based learning.

\section{Epigraph}

'A radiologist is a clinician who has sacrificed one of the greatest glories of the practice of medicine and its greatest responsibility - the daily contact with the ill and their families - in order to concentrate more on the essence of our profession, the pathology of the living. This he sees through the medium of shadows which has left him open to the charge of not quite being a clinician. But shadows after all are real. Seeing is done with the mind. The camera does not see, it records. The clinician at the bedside sees the patient and imagines the lesion. The radiologist sees the lesion and imagines the patient'.

[Harry Z. Mellins, MD (1921 - 2009); former Professor of Radiology, Harvard Medical School]

\section{Introduction}

Clinical and non-clinical knowledge, procedural expertise, computer literacy/proficiency in information technology, knowledge of diagnostics, and non-interpretive skills are an integral part of postgraduate training in radiology: $:^{1,2,3}$

A Radiologist is a specialist medical doctor who has had postgraduate training in performing and interpreting diagnostic imaging tests, and carrying out interventional procedures or treatments, using X-ray, ultrasound, and Magnetic Resonance Imaging equipment. ${ }^{4,5}$

A medical speciality is a branch/subdivision/subset of medicine that focuses on or is devoted to a specific or defined category of patients, illnesses or disorders, expertise or skills, or philosophy or theory. ${ }^{6}$ Radiology, Internal Medicine, Paediatrics, Otorhinolaryngology (ORL), Ophthalmology, Surgery, and so on, are examples of medical specialities. A physician who has specialised in a medical speciality is a specialist. In contrast, a generalist's competencies, proficiency, interests, and skills/expertise are diverse, eclectic, comprehensive, and unspecialised. In other words, a 
generalist maintains a broad scope of practice. ${ }^{7,8}$ A general radiologist is one who has undergone a radiology residency without completing a fellowship or any other subspeciality training. ${ }^{9}$

A subspeciality is a narrow field of professional knowledge, skills, expertise, and focus within a broader medical speciality: ${ }^{10}$

Subspecialisation entails the devotion of intellectual energies to understand more and more about a narrower aspect of a speciality. It provides an intense exposure to a subspeciality area allowing a focused development of clinical and surgical skills related to that subspeciality area..$^{11,12}$

Subspecialisation requires knowledge, expertise, and practice beyond that of a specialisation. Specific personnel, equipment, technology, dedicated curriculum, accredited training centres, logbooks, exposure to complex cases, high case volumes, subspecialist international journals, international subspecialist societies/associations, and relevant scientific breakthroughs in the field are the sine qua non of subspecialisation. ${ }^{13}$

In essence, a radiology subspeciality should have a unique body of knowledge that cannot be subsumed under general radiology, a peculiar applicability distinct from general radiology, an evidence of improved patient care because of subspecialist input, a structured formal training, and accruable benefits which outweigh any negative impact on the extant general radiology or other radiology subspeciality. ${ }^{14}$

Factors such as the expansive and multifaceted nature of radiology, rapid development of new imaging modalities, the need for subspecialist radiology interpretation for subspecialist referring physicians, more competitive job market, increased prospects of better remuneration, improved professional standing (status symbol), and so on, are the chief drivers of the quest for subspecialisation in radiology. ${ }^{15}$

Existing radiology subspecialities include system-based subspecialities (Cardiovascular Imaging, Chest Imaging, ORL/Dental Imaging, Breast Imaging, Musculoskeletal Imaging, Gastrointestinal Imaging, Uroradiology, Obstetric \& Gynaecological Imaging, Neuroradiology); techniquebased subspecialities (Nuclear Medicine/Radionuclide Radiology, Interventional Radiology [IR]); disease-based subspecialities (Oncological Imaging, Trauma Imaging, Emergency Radiology); age-based subspecialities (Paediatric Imaging); and emerging subspecialities (Global Radiology, Radiology Informatics, Forensic Radiology). ${ }^{16}$

In general, 'radiology' arrived in Africa, not too long after Roentgen discovered X-rays in 1895, when X-ray machines became available in South Africa (1896), ${ }^{17}$ Egypt (1906), ${ }^{18}$ Uganda (1907), ${ }^{19}$ Nigeria (1913), ${ }^{20}$ and so on. However, the commencement of radiology postgraduate residency and subspecialisation in African countries seems to have lagged behind the rest of the world.

An article published in 2019 reported that subspeciality training was available in $0 \%, 55 \%$, and $74 \%$ of African, European, and Asian countries, respectively. ${ }^{21}$ The pros and cons of radiology subspecialisation had been discussed comprehensively by other authors. ${ }^{9,22,23,24,25,26}$

This research aims to investigate the current status of radiology subspecialisation training programmes in Africa and to identify the obstacles to the actualisation of this laudable aspiration. The focus is on the availability of local formal training programmes rather than the presence or absence of practising subspecialist radiologists in the health workforce of the countries evaluated.

\section{Methods}

We searched the literature using Google search engine (primarily), Google Scholar, and African Journal Online. The keywords comprised the name of the countries together with the words radiology, specialisation, and subspecialisation in various combinations. The references cited in the retrieved articles provided additional information. The country reports published by RAD-AID International (https://radaid.org/resource-center/country-reports) were invaluable sources of data. The last search was performed on 20th April 2021. A few North African radiologists were also contacted by email to provide information about their countries, but we received a response from only one of them.

\section{Results}

A summary of available subspecialist radiology training programmes in different African countries is presented in Table 1. Only those countries with well-established radiology residency training were assessed for the availability of formal subspecialisation training locally. Eight (Egypt, Ethiopia, Kenya, Morocco, Nigeria, South Africa, Tanzania, and Tunisia) out of the 18 African countries with well-established radiology residency training have local subspecialist training programmes. East Africa (three countries), North Africa (three countries), Southern Africa (one country), and West Africa (one country) make up the regional spread. Data/ information on subspecialisation were unavailable for three of the 18 countries (Algeria, Libya, and Senegal). Except for Tanzania, all the countries with subspecialisation training programmes have $\geq 100$ radiologists in their workforce.

\section{Paediatric radiology}

Paediatric radiology subspeciality training is available in South Africa, Ethiopia, and possibly, Tunisia.

\section{South Africa}

In South Africa, paediatric radiology subspeciality training began in 2009 at the Red Cross War Memorial Hospital in Cape Town. It is a 1-year programme after which successful candidates are awarded a postgraduate diploma in paediatric radiology by the University of Cape Town. Subspeciality training in paediatric imaging is also available at the Nelson Mandela Children's Hospital in Johannesburg (opened officially in December 2016). ${ }^{27}$ 
TABLE 1: Current status of radiology subspecialisation in Africa.

\begin{tabular}{|c|c|c|c|c|c|c|c|c|}
\hline Country & Population & Year estimated & $\begin{array}{c}\text { Radiologist } \\
\text { workforce }\end{array}$ & Year estimated & $\begin{array}{l}\text { Radiology } \\
\text { residency }\end{array}$ & Duration (years) & Qualification(s) awarded & $\begin{array}{c}\text { Subspeciality radiology } \\
\text { training program }\end{array}$ \\
\hline Algeria ${ }^{29,30}$ & 43851044 & 2020 & 788 & 2012 & Yes & 4 & NA & NA \\
\hline Cameroon $^{31}$ & 26545863 & 2020 & 50 & 2017 & Yes & 4 & MD & None \\
\hline $\mathrm{CIV}^{32,33}$ & 26378274 & 2020 & 60 & 2011 & Yes & 4 & $\begin{array}{l}\text { Diploma/Certificate of } \\
\text { Specialized Studies }\end{array}$ & None \\
\hline Egypt $^{29,30,34}$ & 102334404 & 2020 & 1250 & 2012 & Yes & 5 & MSc or MD or FEBR & $I R ; W I$ \\
\hline Ethiopia ${ }^{29,30}$ & 114963588 & 2020 & 100 & 2012 & Yes & 4 & MD & PR \\
\hline Kenya ${ }^{29,36}$ & 53771296 & 2020 & 146 & 2020 & Yes & 6 & MMed & IR \\
\hline Libya $^{37}$ & 6871292 & 2020 & 55 & 2017 & Yes & NA & $\begin{array}{l}\text { Libyan Fellowship Certificate/ } \\
\text { Medical Specialties Board } \\
\text { Certificate }\end{array}$ & NA \\
\hline Mauritius $s^{38,39}$ & 1271768 & 2020 & 54 & 2020 & Yes & NA & MD & None \\
\hline Morocco ${ }^{40}$ & 36910560 & 2020 & 338 & 2018 & Yes & NA & $M D$ & $\mathbb{R}$ \\
\hline Nigeria $^{20}$ & 206139589 & 2020 & 355 & 2011 & Yes & 5 & $\begin{array}{l}\text { FWACS or FMCR or MD or } \\
\text { combination }\end{array}$ & PR \\
\hline Senegal ${ }^{29}$ & 16743927 & 2020 & NA & - & Yes & $\geq 7$ & NA & NA \\
\hline South Africa ${ }^{29,43,44}$ & 59308690 & 2020 & 650 & 2015 & Yes & 5 & $\begin{array}{l}\text { FCRadSA or MMed or } \\
\text { combination }\end{array}$ & $P R ; I R$ \\
\hline Sudan 45,46 & 43849260 & 2020 & 30 & 2013 & Yes & 4 & $M D$ & None \\
\hline Tanzania ${ }^{29,47}$ & 59734218 & 2020 & 60 & 2020 & Yes & 3 & MMed & IR \\
\hline Tunisia ${ }^{48}$ & 11818619 & 2020 & 750 & 2016 & Yes & 5 & MD & IR; PR \\
\hline Uganda ${ }^{29,49}$ & 45741007 & 2020 & 50 & 2019 & Yes & 3 & MMed & None \\
\hline
\end{tabular}

Note: Current population estimates obtained from Worldometer elaboration of the latest United Nations data (https://www.worldometers.info/world-population/).

CIV, Cote D'Ivoire; FCRadSA, Fellow College of Radiology of South Africa; FEBR, Fellow Egyptian Board of Radiology; FGCPS, Fellow Ghana College of Physicians \& Surgeons; FMCR, Fellow (of the) Medical College (in) Radiology (Nigeria); FWACS, Fellow West African College of Surgeons; IR, Interventional Radiology; MD, Doctor of Medicine; MMed, Master of Medicine; MSc, Master of Science; NA, Not Available; PR, Paediatric Radiology; WI, Women Imaging.

Also in South Africa, the World Federation for Paediatric Imaging (WFPI), under the auspices of the William Shiels memorial foundation, offers a 3-month funded paediatric radiology observership in South Africa, at either the Red Cross War Memorial Children's Hospital in Cape Town or the Nelson Mandela Children's Hospital in Johannesburg. The first WFPI Observer / Fellow completed her Observership in 2018. The 2020 programme was shelved because of the COVID-19 pandemic. ${ }^{28}$

\section{Ethiopia}

Efforts to set up a paediatric radiology subspeciality training programme at the Department of Radiology, Addis Ababa University, Ethiopia commenced in 2012 as a 4-year outreach programme by paediatric radiology staff of the Children's Hospital of Philadelphia (CHOP), Perelman School of Medicine, University of Pennsylvania, USA (CHOP Paediatric Radiology International Outreach Programme) in collaboration with the WFPI. The 2-year-long subspeciality fellowship programme finally took off in 2015 and has already produced two locally trained paediatric radiologists (graduated in 2017). There are three new trainees in the programme as of 2019. $50,51,52$

\section{Tunisia}

Professor Hassen El-Akeba Gharbi is a celebrated Tunisian paediatric radiologist and past president of the World Federation for Ultrasound in Medicine and Biology (WFUMB), who started a paediatric radiology department at the Children's Hospital, Tunis, Tunisia, in 1970. He taught paediatric radiology at the hospital, and the programme still exists. ${ }^{53}$ Only the radiology department of the children's hospital in Tunis can train paediatric radiologists (Prof. Ibtissem Bellagha, 2020, Personal email communication, 08 October)

\section{Nigeria}

A recent article from Nigeria indicates that paediatric radiology subspeciality training became available under the auspices of the West African Postgraduate Medical College in 2019. It appears that the programme is still nascent and the details are sketchy. ${ }^{54}$

\section{Continental Professional Association/Society}

The African Society of Paediatric Imaging (AfSPI) was formalised on 30th October 2012.55

\section{Interventional radiology}

Subspeciality training in IR is available in Egypt, South Africa, Kenya, Tanzania, Tunisia, and Morocco. ${ }^{29,56,57}$

\section{South Africa}

Formal 1-year subspeciality training in IR was established at the University of the Orange Free State (UOFS), Bloemfontein, in 2002. A diploma in IR of the UOFS is conferred at the successful completion of the programme. ${ }^{57}$ More training centres may have been established in South Africa thereafter.

\section{Egypt}

In Egypt, there is no structured nationwide IR fellowship yet; however, IR subspeciality certification is currently organised via two pathways for doctors who have already completed their diagnostic radiology training. Firstly, there 
is institution-based training in which Fellows rotate through 4-5 self-selected training centres from a pool of 10 accredited training institutes/university hospitals. Secondly, candidates can apply to the Egyptian Board of Interventional Radiology (currently the only official IR specialty board certificate in Egypt) for a 2-year training program. ${ }^{56,58,59}$

\section{Tanzania}

The Tanzanian 2-year IR subspeciality curriculum took off in October 2019 at the Muhimbili National Hospital (MNH) in Dar es Salaam. ${ }^{60}$ The first class of three fellows is expected to graduate by September 2021 with a Master of Science in Interventional Radiology to be awarded by the Muhimbili University of Health and Allied Sciences (MUHAS). The Tanzanian IR project was midwifed by the RAD-AID International IR program in collaboration with academic institutions in the United States and Europe. ${ }^{47,60,61}$

\section{Kenya}

In June 2020, the University of Nairobi's senate approved a 2-year IR fellowship domiciled at the university's Department of Diagnostic Imaging and Radiation Medicine. The inaugural class of Kenyan Diagnostic radiologists would be enrolled later in 2020. This programme was established with the help of the University of North Carolina at Chapel Hill (Division of Vascular-Interventional Radiology \& Division of Radiologic Science) and RAD-AID International. ${ }^{62}$

Finally, there is circumstantial evidence of IR subspeciality training in Morocco and Tunisia, ${ }^{59}$ but details of the programmes could not be obtained.

\section{Continental Professional Association/Society}

The Society of African Interventional Radiology and Endovascular Therapy (SAFIRE) is the continental professional association of interventional radiologists in Africa. Some of the North African countries are also members of the Pan Arab Interventional Radiology Society (PAIRS).

\section{Women's imaging}

There is anecdotal evidence of institution-based subspeciality training in Women's Imaging at Cairo University in Egypt.

\section{Discussion}

As stated at the introduction, a previous article published in 2019 reported inaccurately that subspeciality training was available in $0 \%$ of African countries. This misinformation is likely because of the general paucity of information on the evolution of radiology in African countries. As can be seen from our data, IR training had been available in South Africa since 2002. The quest for radiology subspecialisation seems to have accelerated in the last 5 years across the continent. In spite of this positive development, many hurdles still remain.

\section{Obstacles to the establishment of radiology subspecialisation in Africa}

Africa, being a continent of mostly developing and underdeveloped countries, faces many challenges to the smooth implementation of radiology subspecialisation. Some of these obstacles include lack of funding, equipment and infrastructure deficit, unavailability of expertise, politics, emigration of radiologists, perfectionism, and so on.

\section{Funding}

Generally, the health sector is not adequately funded by many African governments and other stakeholders. The improvement of any field or speciality requires adequate funding for optimal growth and development. Sufficient funding allows for proper training of radiologists and scholarly research in the field of radiology.

\section{Equipment and infrastructure}

Modern equipment and infrastructure are crucial to the training of competent subspecialist radiologists. The poor funding of health care in many African nations has made it impossible to acquire new equipment. These inadequacies impede the creation of the top-level educational environment required for specialist and subspecialist tutoring. ${ }^{63}$

\section{Expertise}

The quality of experts in a field is a product of the training that the specialists had received. It takes a subspecialist to train a subspecialist. Currently, many African countries have insufficient subspecialist manpower, which makes it difficult to initiate subspecialisation training programmes.

\section{Emigration}

Many African medical graduates aim to leave the continent for greener pastures abroad. This medical exodus robs the continent of critically needed expertise. ${ }^{64,65}$ The mass emigration further worsens the already low radiologist-to-population ratio in many African countries.

African radiologists seeking subspecialisation often travel outside Africa to train, but many of them do not return to their home country once they find better opportunities abroad. If subspecialisation programmes are established locally, the attrition of African radiologists might be mitigated. ${ }^{66,67}$

\section{Politics}

Sometimes, obtaining approval for new programmes requires savvy political manoeuvring, lobbying, and horse-trading. Bureaucratic red tape is a feature of governmental regulatory agencies worldwide, and African nations are no different. Radiology is a relatively 'invisible'/'behind-the-scenes' medical speciality. Consequently, it might be an uphill task to secure governmental backing and funding for programmes without accruable political mileage. ${ }^{68}$ Interprofessional rivalries at the universities and teaching 
hospitals could also derail the successful take-off of new training programmes. ${ }^{69}$

\section{Recommendations}

Given the perennial obstacles to subspecialisation enumerated above, especially funding constraints, African radiologists (with foreign collaboration when needed) can leverage existing and emerging technologies and innovative training/learning methods to streamline the training of subspecialist radiologists.

Web-based training was piloted in Ethiopia over a 20-month period using pre-recorded online lectures, case reviews, and learning modules, overseen by subspeciality-trained radiologists of the Johns Hopkins University School of Medicine..$^{21}$ A similar web-based learning tool for paediatric radiology (with users all over the United States and 53 other countries) is used to deliver paediatric radiology curriculum internationally by paediatric radiologists in the USA. ${ }^{70,71}$ Web-based training is cheaper, adaptable, more accessible, and effective..$^{21,72}$

The European diploma in emergency radiology subspeciality is delivered using a combination of self-directed learning, webinars, workshops, research \& teaching, as well as on-thejob training. ${ }^{73}$ Electronic teaching files and internet-accessible case collections are also being used increasingly for radiology subspecialisation training in other European countries with limited access to complex equipment. ${ }^{25}$

Simulation-based technology and immersive training environment for IR have also been proposed.74,75

A complementary business model of medical subspeciality training that incorporates the private sector has been developed for reproductive medicine in South Africa by Dalmeyer et al. ${ }^{76,77}$ The authors are convinced that the model can be applied to other subspecialities.

\section{Conclusion}

There is limited availability of subspecialist radiology training in African countries. Cost-effective and innovative approaches to training are needed to address this deficit.

This study was limited by unavailability of data on subspecialisation in Algeria, Libya, and Senegal.

\section{Acknowledgements Competing interests}

The authors declare that they have no financial or personal relationships that may have inappropriately influenced them in writing this article.

\section{Authors' contributions}

E.P.I. and B.M.I. conceptualised, designed and wrote the article. All the authors assisted with literature review, revision and approved the final draft.

\section{Ethical considerations}

This article followed all ethical standards for research.

\section{Funding information}

This research received no specific grant from any funding agency in public, commercial or not-for-profit sectors.

\section{Data availability}

Data sharing is not applicable to this article as no new data were created or analysed in this study.

\section{Disclaimer}

The views and opinions expressed in this article are those of the authors and do not necessarily reflect the official policy or position of any affiliated agency of the authors.

\section{References}

1. Rahim S, Ros P. Moving away from spoon-feeding as a teaching style in radiology Am J Roentgenol. 2016;207(6):1232-1238. https://doi.org/10.2214/AJR.16.16694

2. Imanzadeh A, Pourjabbar S, Mezrich J. Medicolegal training in radiology; an overlooked component of the non-interpretive skills curriculum. Clin Imaging. 2020;65:138-142. https://doi.org/10.1016/j.clinimag.2020.04.002

3. Murphy AN, Sheehy NP, Kavanagh PV. Non-interpretive radiology: An Irish perspective. Clin Radiol. 2018;73(5):494-498. https://doi.org/10.1016/j. crad.2017.10.023

4. Royal Australian and New Zealand College of Radiologists (RANZCR). A career in clinical radiology [homepage on the Internet]. [cited 2021 Mar 23]. Available from: https://www.ranzcr.com/join-our-professions/clinical-radiology/a-careerin-clinical-radiology

5. Sanghvi $D$, Harisinghani MG. Modalities in modern radiology: A synopsis. Postgrad Med. 2010;56(2):85-87. https://doi.org/10.4103/0022-3859.65282

6. WebMD. Different types of doctors: Find the specialist you need [homepage on the Internet]. WebMD. [cited 2021 Mar 24]. Available from: https://www.webmd. com/health-insurance/insurance-doctor-types

7. Leinster S. Training medical practitioners: Which comes first, the generalist or the specialist? J R Soc Med. 2014;107(3):99-102. https://doi.org/10.1177/014107 6813519438

8. Parnis $\mathrm{S}$. Will subspecialisation benefit the practice of Australasian emergency medicine? No: Will subspecialisation benefit the practice of Australasian emergency medicine? No. Emerg Med Australas. 2016;28(4):473-474. https:// doi.org/10.1111/1742-6723.12633

9. Strax R. Counterpoint: Generalism vs subspecialization - The ACR should develop a practice model to support general radiologists. J Am Coll Radiol. 2012;9(8):537-538. https://doi.org/10.1016/j.jacr.2012.04.003

10. Subspecialty. In: Wikipedia [homepage on the Internet]. 2019 [cited 2020 Oct 01]. Available from: https://en.wikipedia.org/w/index.php?title=Subspecialty\&old id $=927594101$

11. Cassel CK, Reuben DB. Specialization, subspecialization, and subsubspecialization in internal medicine. N Engl J Med. 2011;364:1169-1173. https://doi.org/10.1056/ NEJMsb1012647

12. Musa KO, Aribaba OT, Rotimi-Samuel A, Oluleye TS, Idowu OO, Onakoya AO. Subspecialty preferences among ophthalmology resident doctors in Nigeria. Niger J Ophthalmol. 2017;25(2):123-128.

13. European Association of Perinatal Medicine (EAPM/EBCOG). Subspecialty in obstetrics and gynaecology feto-maternal and perinatal medicine [homepage on the Internet]. [cited $2021 \mathrm{Mar} 24$ ]. Available from: http://www.europerinatal.eu/ filesDoc/EAPM_TRAINING_PROGRAMME.pdf

14. Edmonds MJ, Hamilton S, Brichko L. Subspecialisation in emergency medicine: A specialty at the crossroads. Emerg Med Australas. 2016;28(4):462-464. https:// doi.org/10.1111/1742-6723.12629

15. Amaraegbulam PI. Orthopaedic subspecialisation: The Nigerian experience. Niger J Orthop Trauma. 2018;17(1):8-11. https://doi.org/10.4103/njot.njot_2_18

16. Royal College of Radiologists. Curricula for subspeciality training [homepage on the Internet]. 1999 [cited 2021 Mar 24]. Available from: https://www.rcr.ac.uk/system/ files/publication/field_publication_files/Appendix\%201_Curricula_Subsp.pdf

17. De Villiers JC. The origins and early use of radiology in South Africa: Radiography in South Africa before 1899. S Afr J Radiol. 2000;4(1):12-9, 32. https://doi. org/10.4102/sajr.v4i1.1548

18. Gardner RA. The organisation of the teaching of medical radiology in Egypt. Acta Radiol. 1930;Original Series 11(4_Suppl):112-115. https://doi.org/10.1177/ $02841851300110 \$ 415$ 
19. Mengo Hospital. In: Wikipedia [homepage on the Internet]. 2021 [cited 2021 Mar 26]. Available from: https://en.wikipedia.org/w/index.php?title=Mengo Mar 26]. Available from:

20. Idowu BM. Postgraduate radiology education in Nigeria: Looking backward and forward. S Afr J Radiol. 2018;22(1):1362. https://doi.org/10.4102/sajr.v22i1.1362

21. Haj-Mirzaian A, Sethi N, De Francesca B, Sahni S, Zaheer A. Web-based radiology subspecialty training program: Pilot feasibility and effectiveness analysis on Ethiopian radiologists. Acad Radiol. 2020;27(2):293-299. https://doi.org/ 10.1016/j.acra.2019.02.025

22. European Society of Radiology (ESR). Summary of the proceedings of the International Summit 2015: General and subspecialty radiology. Insights Imaging. 2016;7:1-5. https://doi.org/10.1007/s13244-015-0453-6

23. Oren O, Gersh BJ, Bhatt DL. On the pearls and perils of sub-subspecialization. Am J Med. 2020;133(2):158-159. https://doi.org/10.1016/j.amjmed.2019.06.052

24. Mohan C. Subspecialization in radiology - Is it time to hatch out of the cocoon? Indian J Radiol Imaging. 2017;27:261-262. https://doi.org/10.4103/ijri.IJRI 345_17

25. European Society of Radiology (ESR) 2009. The future role of radiology in healthcare. Insights Imaging. 2010;1:2-11. https://doi.org/10.1007/s13244-009$0007-x$

26. Rockall A, Brady AP, Derchi LE, European Society of Radiology (ESR). The identity and role of the radiologist in 2020: A survey among ESR full radiologist members. Insights Imaging. 2020;11:130. https://doi.org/10.1186/s13244-020-00945-9

27. World Federation of Paediatric Imaging (WFPI). A global mapping of paediatric radiologists and paediatric radiology training 2017 [homepage on the Internet] [cited $2021 \mathrm{Apr}$ 20]. Available from: http://www.wfpiweb.org/Portals/7/ Workrooms/Mapping-Framework-WFPI-EXCOM-circulation.pdf

28. William Shiels Memorial Foundation. WFPI - Shiels foundation observership in South Africa [homepage on the Internet]. [cited 2021 Mar 26]. Available from: https://www.wfpiweb.org/Fellowships/ObservershipinSouthAfrica.aspx

29. Rehani B, Brown I, Dandekar S, et al. Radiology education in Africa: Analysis of results from 13 African countries. J Am Coll Radiol JACR. 2017;14(2):247-252. https://doi.org/10.1016/j.jacr.2016.08.012

30. Kawooya MG. Training for rural radiology and imaging in sub-saharan Africa: Addressing the mismatch between services and population. J Clin Imaging Sci. 2012;2:37. https://doi.org/10.4103/2156-7514.97747

31. Mankaa WE. Cameroon Country Report [homepage on the Internet]. RAD-AID 2017 [cited 2021 Mar 26]. Available from: https://rad-aid.org/wp-content/ uploads/Cameroon-Country-Report.pdf

32. Dada O. Côte d'Ivoire Country Report [homepage on the Internet]. RAD-AID International [cited 2021 Mar 26]. Available from: https://rad-aid.org/wpcontent/uploads/IvoryCoast-CR.pdf

33. Monu JUV, Hewlett V, Ostlere S. International Skeletal Society outreach in SubSaharan West Africa. Skeletal Radiol. 2011;40:251-254. https://doi.org/10.1007/ s00256-010-1084-0

34. Abdelaziz A, Kassab SE, Abdelnasser A, Hosny S. Medical education in Egypt: Historical background, current status, and challenges. Health Prof Educ. 2018;4(4):236-244. https://doi.org/10.1016/j.hpe.2017.12.007

35. Edzie EKM, Dzefi-Tettey K, Gorleku PN, et al. Application of information and communication technology in radiological practices: a cross-sectional study among radiologists in Ghana. Journal of Global Health Reports. 2020;4:e2020046

36. Oketch A. Two specialists lose battle against virus [homepage on the Internet]. Nation; 2020 [cited 2020 Nov 23]. Available from: https://nation.africa/kenya/ news/two-specialists-lose-battle-against-virus-3206260

37. State of Libya, Ministry of Health (Health Information and Documentation Center) The Libyan Health System: Study of medical and allied health education and training institutions (2018) [homepage on the Internet]. 2018 [cited 2021 Mar 26]. Available from: https://www.humanitarianresponse.info/sites/www. humanitarianresponse.info/files/documents/files/study_of_medical_and_allied health_institutes_of_libya.pdf

38. Medical Council of Mauritius. Mauritius doctors register [homepage on the Internet]. [cited 2021 Mar 26]. Available from: http://medicalcouncilmu.org/ doctor

39. University of Technology Mauritius. University of Technology, Mauritius. In Wikipedia [homepage on the Internet]. 2021 [cited 2021 Mar 26]. Available from: https://en.wikipedia.org/w/index.php?title=University_of_Technology, Mauritius\&oldid=1011716738

40. International Organization for Migration (IOM). Morocco Country Fact Sheet 2020 [home page on the Internet]. 2020 [cited 2021 Mar 26]. Available from: https:// files.returningfromgermany.de/files/Country $\% 20$ Fact $\% 20$ Sheet $\% 20$ Morocco\%202020\%20ENG.pdf

41. Cancedda C, Cotton P, Shema J, et al. Health professional training and capacity strengthening through international academic partnerships: The first five years of the human resources for health program in Rwanda. Int J Health Policy Manage. 2018;7(11):1024-1039. https://doi.org/10.15171/ijhpm.2018.61

42. Harvard Medical School, Rosman D, Nshizirungu J, et al. Imaging in the Land of 1000 Hills: Rwanda radiology country report. J Glob Radiol. 2015;1(1):6. https:// doi.org/10.7191/jgr.2015.1004

43. Techsmart. Shortage of radiologists in SA requires innovative solution [homepage on the Internet]. [cited 2021 Mar 26]. Available from: http://www.techsmart. co.za/business/Shortage-of-radiologists-in-SA-requires-innovative-solution.html

44. De Vries C. Training for radiologists. S Afr J Radiol. 2004;8(2):a125. https://doi. org/10.4102/sajr.v8i2.125
45. Nimir M, Elzein A. Sudan country reports [homepage on the Internet]. RAD-AID International; 2013 [cited 2021 Mar 26]. Available from: https://rad-aid.org/wpcontent/uploads/Sudan-CR.pdf

46. Sudan Medical Specialisation Board (SMSB). Clinical MD in radiology and imaging [homepage on the Internet]. 2015 [cited 2021 Mar 27]. Available from: https:// www.yumpu.com/en/document/view/31353996/clinical-md-in-radiology-andimaging-sudan-medical-

47. Peltier A. The Tanzania interventional radiology initiative: An update from the Road2IR global outreach program [homepage on the Internet]. IOLearning; 2020 [cited 2021 Mar 26]. Available from: https://www.interventionaloncology360. com/content/tanzania-interventional-radiology-initiative-update-road2ir-globaloutreach-program

48. Informatics Drives Radiology Today. Interview with Hassen Gharbi [homepage on the Internet]. Leaders; 2016 [cited 2021 Mar 26]. Available from: https://www. leaders.com.tn/article/20210-informatics-drives-radiology-today-interview-withhassen-gharbi

49. Marshall S. Establishing an interventional radiology unit in Uganda [homepage on the Internet]. Interventional News; 2019 [cited 2020 Oct 06]. Available from: https://interventionalnews.com/uganda-interventional-radiology-unit/

50. World Federation of Pediatric Imaging (WFPI). Pediatric radiology education in Ethiopia [homepage on the Internet]. 2017 [cited 2021 Mar 26]. Available from: https://www.wfpiweb.org/Outreach/WorldwideEducationallnitiatives/ Ethiopia.aspx

51. Zember J, Reid J, Gorfu Y, Solomon DZ, Darge K. Pediatric radiology fellowship creation as an international education outreach effort in Ethiopia. J Grad Med Educ. 2020;12(1):98-103. https://doi.org/10.4300/JGME-D-19-00291.1

52. Zewdneh D, Gorfu Y, Darge K, Keller M, Jaramillo D. Pediatric radiology fellowship curriculum, Addis Ababa University Faculty of Medicine [homepage on the Internet]. Addis Ababa University; 2014 [cited 2021 Mar 26]. Available from: https://www.wfpiweb.org/Portals/7/Education/Pediatric\%20Radiology\%20 Curriculum_Addis\%20Ababa\%20University-CHOP_2014_KD.pdf

53. Society for Pediatric Radiology (SPR). Professor Hassen A. Gharbi (SPR 2007 Honorary Member). Pediatr Radiol. 2008;38:177.

54. Omidiji OA, Atalabi OM. Pediatric radiology as a subspecialty in Nigeria: To be or not to be? Pediatr Radiol. 2021;51:592-593. https://doi.org/10.1007/s00247020-04772-4

55. The World Federation of Pediatric Imaging. African Society of Paediatric Imaging (AfSPI) [homepage on the Internet]. 2021 [cited 2021 Mar 25]. Available from https://www.wfpiweb.org/Home/AfricanSocietyofPaediatriclmaging(AfSPI).aspx

56. Khafagy RM. Egyptian females' experience in interventional radiology field. Arab J Interv Radiol. 2019;3(1):1. https://doi.org/10.4103/AJIR.AJIR_28_18

57. Duncan. Interventional radiology establishes itself in South Africa [homepage on the Internet]. Diagnostic imaging. 2003 [cited 2021 Mar 26]. Available from: the Internet]. Diagnostic imaging. 2003 [cited 2021 Mar 26]. Available from: https://www.diag

58. El Tawab KAA, Abdel Wahab SM. The status of interventional radiology training: The Egyptian experience. Arab J Interv Radiol. 2020;4(1):3. https://doi. org/10.4103/AJIR.AJIR_25_19

59. Khafagy RTM, Tawab KAAE, Hammami N, Bouklata S, Findeiss L, Arabi M. Experience of women in IR in the Arab world: Survey by the Pan Arab Interventional Radiology Society. J Vasc Interv Radiol. 2020;31:1158-1163. https://doi. org/10.1016/j.jvir.2020.03.019

60. Laage Gaupp FM, Solomon N, Rukundo I, et al. Tanzania IR initiative: Training the first generation of interventional radiologists. J Vasc Interv Radiol. 2019;30(12):2036-2040. https://doi.org/10.1016/j.jvir.2019.08.002

61. Interventional News. RSNA grant enables the establishment of an IR service in Tanzania [homepage on the Internet]. Interventional News; 2020 [cited $2021 \mathrm{Ma}$ 27]. Available from: https://interventionalnews.com/rsna-grant-enables-theestablishment-of-an-ir-service-in-tanzania/

62. Plummer M. Dixon leads collaboration to start Kenya's first interventional radiology training program [Internet]. Newsroom; 2020 [cited 2020 Oct 08]. Available from: https://news.unchealthcare.org/2020/07/dixon-leads-collaboration-to-startkenya2019s-first-interventional-radiology-training-program/

63. Idowu B, Okedere T. Diagnostic radiology in Nigeria: A country report. J Glob Radiol. 2020;6(1):1072. https://doi.org/10.7191/jgr.2020.1072

64. Child K. SA's radiologists flocking to write equivalency exams in UK, Australia and NZ [homepage on the Internet]. Medical Brief; 2019 [cited 2021 Mar 28]. Available from: https://www.medicalbrief.co.za/archives/sas-radiologists-flocking-to-writefrom: https://www.medicalbrief.co.za/archivis
equivalency-exams-in-uk-australia-and-nz/

65. Moodley H. A survey of the factors involved in the emigration of South African radiologists [homepage on the Internet] [Master of Medicine Thesis]. Johannesburg: University of the Witwatersrand; 2017. Available from: http:// wiredspace.wits.ac.za/handle/10539/25340

66. Amuakwa-Mensah F, Nelson AA. Retention of medical doctors in Ghana through local postgraduate training. J Educ Pract. 2014;5:120-133.

67. Gyedu A, Debrah S, Agbedinu K, et al. In-country training by the Ghana College of Physicians and Surgeons: An initiative that has aided surgeon retention and distribution in Ghana. World J Surg. 2019;43:723-735. https://doi.org/10.1007/ s00268-018-4840-2

68. McFubara KG, Etekpe A. Medicine and politics: The convergence from a Nigerian perspective. Glob J Soc Sci. 2018;17:109-116. https://doi.org/10.4314/gjss. v17i1.10

69. Omisore AG, Adesoji RO, Abioye-Kuteyi EA. Interprofessional rivalry in Nigeria's health sector: A comparison of doctors and other health workers' views at Secondary Care Center. Int Q Community Health Educ. 2017;38(1):9-16. https:// doi.org/10.1177/0272684X17748892 
70. Chudakoff J, Obuchowski N, Mehta N, Reid J. Worldwide utilization of a webbased learning tool for pediatric radiology. AJR Am J Roentgenol. 2013;200:974-979. https://doi.org/10.2214/AJR.12.10443

71. Reid JR, Goske MJ, Hewson MG, Obuchowski N. Creating an international comprehensive web-based curriculum in pediatric radiology. AJR Am J Roentgenol. 2004;182(3):797-801. https://doi.org/10.2214/ajr.182.3.1820797

72. Hoa D, Micheau A, Gahide G. Creating an interactive web-based e-learning course: A practical introduction for radiologists. RadioGraphics. 2006;26(6):e25-e25. https://doi.org/10.1148/rg.e25

73. Wagner MG, Fischer MR, Scaglione $M$, et al. Subspecialisation in emergency radiology: Proposal for a harmonised European curriculum. GMS J Med Educ. $2017 ; 34: 61$.
74. Mandal I, Ojha U. Training in interventional radiology: A simulation-based approach. J Med Educ Curric Dev. 2020;7:2382120520912744. https://doi. org/10.1177/2382120520912744

75. McCarthy CJ, Yu AYC, Synho D, Dawson SL, Uppot RN. Interventional radiology training using a dynamic medical immersive training environment (DynaMITE). J Am Coll Radiol. 2018;15:789-793. https://doi.org/10.1016/j.jacr.2017.12.038

76. Dalmeyer P, Struwig M, Kruger T. A trial model for medical subspecialty training in South Africa. Facts Views Vis Obgyn. 2016;8:55-58.

77. Dalmeyer JPF. A business model for medical subspecialist education in South Africa [homepage on the Internet] [PhD thesis]. South Africa, Port Elizabeth: A the Nelson Mandela Metropolitan University of South Africa; 2015 [cited 2020 Apr 20]. Available from: https://tinyurl.com/8u3kjedy 